\title{
PEMAHAMAN TATA CARA BERBISNIS BUSANA MUSLIM MENURUT PRINSIP SYARIAT ISLAM ( STUDI PADA PEDAGANG BUSANA MUSLIM DI PUSAT NIAGA PALOPO)
}

\author{
Takdir $^{1}$ \\ Selvi $^{2}$ \\ takdir@gmail.com
}

\begin{abstract}
This research discusses the Understanding of the Procedures for Doing Muslim Clothing Business According to the Principles of Islamic Sharia (Studies on Muslim Clothing Traders at the Palopo Commercial Center). The purpose of this research is to find out how to trade Muslim clothing according to the principles of Islamic law. In this study, using a qualitative descriptive method, namely, a study aimed at analyzing the phenomenon of events, social activities, attitudes, beliefs, perceptions, thoughts of people individually or in groups. This study concludes that the procedures for trading Muslim clothing according to Islamic law in PNP are a description of the seller's level of understanding of the procedures for doing business in accordance with the principles of Islamic shari'ah. And descriptions that are sold are goods that are good and do not disappoint consumers. Quality and type of goods, some buyers say that the seller is not honest and the quality of the goods. And the buyer feels that the seller applies the element of usury. So it can be concluded that some Muslim clothing traders in Palopo Business Center do not apply Islamic business procedures, but there are some Muslim clothing traders who apply Islamic business procedures.
\end{abstract}

Keywords: Understanding of Business Procedures; Islamic Sharia.

\begin{abstract}
ABSTRAK
Penelitian ini membahas tentang Pemahaman Tata Cara Berbisnis Busana Muslim Menurut Prinsip Syariat Islam (Studi Pada Pedagang Busana Muslim Di Pusat Niaga Palopo). Tujuan dari penelitian ini adalah untuk mengetahui bagaimana tata cara berdagang busana muslim menurut prinsip syariat Islam. Dalam penelitian ini, menggunakan metode deskriptif kualitatif yaitu, suatu penelitian yang ditujukan untuk mendeskripsikan menganalisa fenomena peristiwa, aktivitas sosial, sikap, kepercayaan, persepsi, pemikiran orang secara individual maupun kelompok. Penelitian ini menyimpulkan bahwa tata cara berdagang busana muslim menurut syariat Islam di PNP adalah deskripsi tingkat pemahaman penjual tentang tata cara berbisnis sudah sesuai dengan prinsip syariea Islam. Dan deskripsi yang diperjualkan barang-barang yang bagus dan tidak mengecewakan konsumen. Kualitas dan jenis barang, sebagian pembeli mengatakan bahwa penjual tidak jujur dan kualitas barangnya. Dan Pembeli merasa bahwa penjual menerapkan unsur riba. Jadi dapat
\end{abstract}


disimpulkan bahwa pedagang busana muslim di Pusat Niaga Palopo sebagian tidak menerapkan tata cara bisnis Islam, tetapi ada sebagian pedagang busana muslim menerapkan tata cara bisnis Islam.

Kata Kunci : Pemahaman Tata Cara Berbisnis; Syariat Islam.

\section{PENDAHULUAN}

A. Latar Belakang Masalah

Agama Islam merupakan agama yang diturunkan oleh Allah SWT ke muka bumi menjadi Rahmatan Lil Alamin (Rahmat bagi seluruh alam). Islam tidak hanya mengatur masalah ibadah seorang hamba kepada Tuhannya. Tetapi juga mampu menjawab bentuk tantangan pada setiap zaman, termasuk dalam persoalan ekonomi. Yang dikenal pada saat ini dengan istilah ekonomi Islam.

Kemunculan ekonomi Islam dipandang sebagai sebuah gerakan baru yang disertai dengan misi dekonstruktif atas kegagalan sistem ekonomi dunia dominan selama ini. ${ }^{1}$

Ekonomi Islam diikat oleh seperangkat nilai iman, akhlak, dan moral etik bagi setiap aktifitas ekonominya baik dalam posisinya sebagai konsumen, produsen, distributor, dan lainlain dalam melakukan usahanya serta dalam memperoleh hartanya. ${ }^{2}$

Aktifitas perdagangan merupakan salah satu dari aspek kehidupan yang bersifat horizontal (Hablum Minannas) yang juga mendapatkan penekanan khusus terhadap ekonomi Islam. $^{3}$

Diantaranya dalam QS.Al-jumuah /62:10
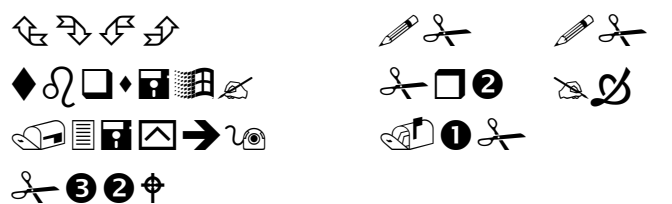
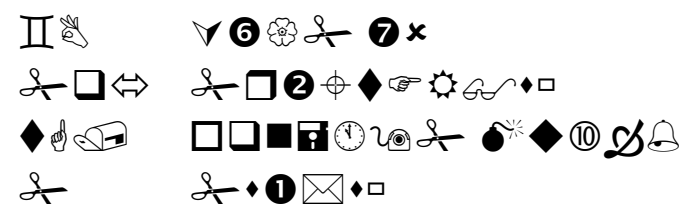
Terjemahnya :

Apabila telah ditunaikan shalat, maka bertebaranlah kamu di muka bumi; dan carilah karunia Allah dan ingatlah Allah banyak-banyak supaya kamu beruntung. ${ }^{4}$

Maksud dari hubungan ayat tersebut diatas yaitu Allah SWT menerangkan bahwa setelah selesai melakukan sholat Jumaat boleh bertebaran dimuka bumi melaksanakan urusan duniawi, berusaha mencaari rezeki yang halal, sesudah menunaikan yang bermanfaat untuk akhirat. Hendaklah mengingat Allah sebanyak-banyaknya dengan menghindarkan diri dari kecurangan, penyelewengan dan lain-lainnya, karena Allah Maha Mengetahui segala sesuatu, yang tersembunyi apalagi nampak nyata.

Setiap Muslim hendaknya memperhatikan bidang dan lapangan profesi yang akan dipilihnya. Kenyataan menunjukkan bahwa apa yang dilakukan oleh sekelompok manusia terdapat pula sejumlah pekerjaan yang haram dan tercela yang bertentangan dengan etos kerja Islami. Dalam Al-Qur"an dan Al-Hadist sebagai sumber etos kerja Islami telah memberikan khiththah antara yang halal dan haram, antara yang terpuji dan tercela. ${ }^{5}$

Pada pokoknya bekerja itu ada dua macam. Pertama, bekerja untuk orang lain. Disini seseorang mendapatkan gaji atau upah dari pihak dimana ia bekerja sebagai imbalan atas kesediaan untuk selalu bekerja pada pihak itu. Kedua bekerja sendiri. Inilah bisnis. Dia tidak mendapatkan gaji dari orang lain. Ia bekerja untuk dirinya sendiri, baik di sektor produksi (barang dan jasa) maupun sektor perdagangan. Bila berhasil, ia akan mendapatkan keuntungan, sebaliknya, bila gagal ia harus menanggung kerugian.

Diera globalisasi sekarang ini, semakin banyak masyarakat menggunakan busana Muslim. Tidak hanya dipakai pada saat momen Hari Raya atau Pengajian, tetapi juga telah menjadi busana sehari-hari. Keadaan ini ternyata ditangkap oleh produsen busana Muslim

untuk terus melakukan inovasi, baik dari bahan maupun modelnya. Berkembang pesat dan mempunyai peluang yang sangat menjanjikan. Dalam ilmu ekonomi, bisnis adalah suatu organisasi yang menjual barang atau jasa kepada konsumen atau bisnis lainnya, uutuk mendapatkan laba. Secara historis, kata bisnis dari bahasa Inggris yaitu business dari kata individu, komunitas, ataupun masyarakat. Dalam artian, sibuk mengerjakan aktivitas dan pekerjaan yang mendatangkan keuntungan.

Pakaian pada dasarnya adalah kebutuhan primer (pokok) yang sangat dibutuhkan oleh manusia di dunia dan perkembangannya cukup signifikan, hal ini terbukti dengan berdirinya pabrik-pabrik pakaian dengan berbagai model dan bahan yang sangat bervariari diseluruh dunia. 
Seorang muslim harus melihat kaidah-kaidah berbusana yang sesuai dengan syariat Islam, supaya apa yang dikenakan dapat dipertanggujawabkan diakhirat kelak dan tidak memicu hal-hal yang tidak diinginkan. Berbeda dengan zaman sekarang banyak sekali model yang tidak sesuai dengan syarie at Islam, sebagai contoh ada model pakaian yang dikenal dengan istilah "you can see” yang artinya kamu boleh melihat, atau bahkan ada yang rela mati-matian untuk menaikkan bagian bawahnya keatas dan ada yang rela untuk diturunkan kebawah. ${ }^{6}$

Dalam ajaran Islam, pakaian bukan semata-mata masalah budaya dan model. Islam menetapkan batasan-batasan tertentu untuk laki-laki maupun perempuan. Khusus untuk muslimah, memilki pakaian khusus yang menujukkan jati dirinya sebagai seorang muslimah. Bila pakaian adat umumnya bersifat lokal, maka pakaian muslimah bersifat universal, dalam arti dapat dipakai oleh muslimah di manapun ia berada.

Ketika Islam datang kedunia ini, ia telah mengangkat posisi perempuan kederajat yang lebih tinggi, memberikan kebebasan, kehormatan, dan hak pribadinya secara merdeka. ${ }^{7}$ Tidak ada lagi penindasan terhadap kaum perempuan, mereka telah dilindungi oleh hak-hak perempuan yang sesungguhnya. Maka dari itu untuk melindungi kehormatan perempuan maka Islam telah mmberikan auran-aturan mengenai cara berprilaku serta cara melindungi diri (meutup aurat).

Melihat respon pasar terhadap produk-produk pakaian Muslim yang cukup bagus, maka terdapat celah peluang bisnis yang bisa digeluti. Bisnis baju Muslim modern, bisa menjadi pilihan usaha selanjutnya. Beberapa tekhnik marketing yang dilakukan oleh pebisnis baju Muslim sebenarnya cukup unik dan layak. Sebagian ada yang memasarkan produk pakaian Muslim dari grosir dengan cara dagang yakni menjual langsung kekonsumen.

Sebuah usaha mampu untuk mempertahankan keunggulan-keunggulan kompetitif hanya untuk periode tertentu karena ditiru pesaing dan melemahkan keunggulan tersebut. Pemasaran memiliki peranan penting bagi suatu usaha untuk mengkomunikasikan keadaan produk dan perusahaan kepada konsumen.

Busana muslim sudah menjadi bagian dari gaya berbusana bagi penduduk yang mayoritas agamanya Muslim, yang berarti ada peluang untuk berbisnis industri pakaian Muslim. Dalam perkembangannya, pakaian Muslim tidak didominasi oleh perusahaan besar saja, namun usaha kecil dan menengah pun memberikan perkembangan perekonomian. ${ }^{8}$

B. Rumusan Masalah

Berdasarkan uraian pada latar belakang masalah di atas, maka dapat diambil rumusan masalah dalam bentuk pertanyaan yaitu : 
Bagaimana tata cara berdagang Busana muslim menurut syariat Islam di Pusat Niaga Palopo?

C. Defenisi Operasional Variabel dan Ruang Lingkup Variabel

Dalam penelitian ini, untuk menghindari kekeliruan dan kesalahpahaman judul proposal ini maka peneliti memberikan defenisi. Yang dimaksud dengan Studi Atas Pemahaman Tata Cara Berbisnis Menurut Prinsip Syariah (studi kasus pada pedagang busana muslim di pusat niaga palopo)

Adapun pengertian yang dimaksud yaitu merupakan aktivitas bisnis ekonomi dengan berbagai bentuk yang tidak ada batasan dalam hal kepemilikan harta baik itu jasa maupun barang, namun dibatasi dalam hal cara memperoleh dan pendayagunaan harta lantaran aturan haram dan halal menurut Islam.

Jadi secara operasional maksud dari proposal ini adalah bagaimana pemahaman masyarakat di Pusat Niaga Palopo tentang tata cara berbisnis menurut prinsip Syarieeah yakni bisnis yang menerapakan nilai-nilai Islam.

\section{Kajian Pustaka}

A. Defenisi Bisnis Islam

Asal kata "bisnis" berasal dari bahasa inggris "business" yang berarti: perusahaan atau usaha. Bisnis dapat diartikan sebagai suatu kegiatan usaha individu yang terorganisasi untuk menghasilkan dan menjual barang dan jasa guna mendapatkan keuntungan dalam memenuhi kebutuhannya. ${ }^{9}$

Islam mewajbkan setiap Muslim, khususnya yang memiliki tanggungan, untuk bekerja. Bekerja merupakan salah satu sebab pokok yang memungkinkan manusia memiliki harta kekayaan. Untuk memungkinkan manusia mencari nafkah, Allah SWT melapangkan bumi serta menyediakan berbagai fasilitas yang dimanfaatkan mencari nafkah. Sebagaimana firman Allah dalam QS. Al-Mulk/67 :15

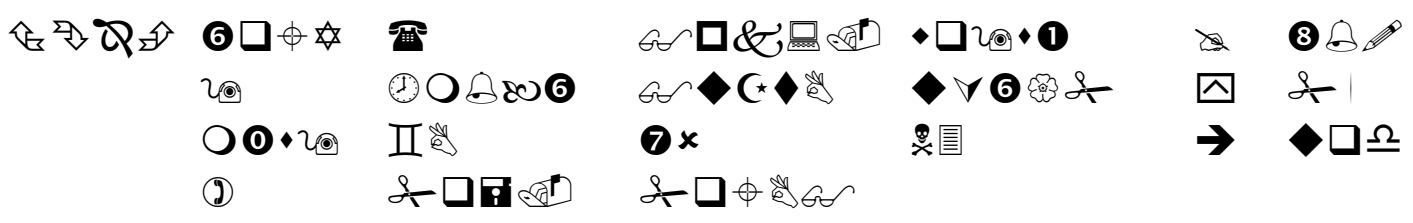




\section{Terjemahnya :}

Dialah yang menjadikan bumi ini mudah bagi kamu, maka berjalanlah di segala penjurunya dan makanlah sebagian dari rezeki-Nya.

B. Etika dalam Berbisnis Syariah

Secara sederhana mempelajari etika dalam bisnis berarti mempelajari tentang mana yang baik atau buruk, benar atau salah dalam dunia bisnis berdasarkan kepada prinsip-prinsip moralitas. Etika bisnis dapat berarti pemikiran atau refleksi tentang moralitas dalam ekonomi dan bisnis. Moralitas disini, sebagaimana disinggung diatas berarti : aspek baik atau buruk, terpuji atau tercela, benar atau salah, wajar atau tidak wajar, pantas atau tidak pantas dari perilaku manusia. Kemudian dalam kajian etika bisnis Islam susunan adjective diatas ditambah dengan halal haram, sebagaimana disinyalir oleh Husein Sahatah, dimana beliau memaparkan sejumlah perilaku etis bisnis (akhlaq al islamiyah) yang dibungkus dengan dhawabith syariyah (batasan syariee ah) ${ }^{10}$

Etika bisnis dalam Islam menurut Sudarsono, mengatakan bahwa, etika Islam adalah doktrin etis yang berdasarkan ajaran-ajaran agama Islam yang terdapat didalam Al-Qur"an dan Sunnah Nabi Muhammad SAW, yang di dalamnya terdapat nilai-nilai luhur dan sifat-sifat yang terpuji. ${ }^{11}$

Sistem etika berbisnis dalam Islam adalah sebagai berikut:

a. Berbagai tindakan ataupun keputusan disebut etis bergantung pada niat individu yang melakukannya. Allah maha kuasa dan mengetahui apapun niat kita sepenuhnya dan secara sempurna.

b. Niat baik yang diikuti tindakan yang baik akan dihitung sebagai ibadah. Niat yang halal tidak dapat mengubah tindakan yang haram menjadi halal.

c. Islam memberikan kebebasan kepada individu untuk percaya dan bertindak berdasarkan apapun keinginannya, namun tidak dalam hal tanggung jawab dan keadilan.

d. Percaya kepada Allah memberi individu kebebasan sepenuhnya dalam hal apa pun dan siapa pun kecuali Allah.

e. Keputusan yang menguntungkan kelompok mayoritas ataupun minoritas tidak secara langsung berarti etis dalam dirinya. Etika bukanlah permainan mengenai jumlah.

f. Islam menggunakan pendekatan terbuka terhadap etika, bukan sebagai sistem yang tertutup, dan berorientasi diri sendiri. Egoisme tidak mendapatkan tempat dalam ajaran Islam. g. Keputusan etis harus didasarkan pada pembacaan secara bersama-sama antara al-Qurean dan alam semesta.

h. Tidak seperti sistem etika yang diyakini banyak agama lain, Islam mendorong umat 
manusia untuk melaksanakan tazkiyah melalui partisipasi aktif dalam kehidupan ini. Dengan berperilaku secara etis ditengah godaan ujian dunia. Kaum Muslimin harus mampu memberikan ketaatan kepada Allah. ${ }^{12}$

C. Defenisi Busana Muslim

1. Busana menurut pandangan Islam

Busana menurut bahasa adalah segala sesuatu yang menempel pada tubuh dari ujung rambut sampai ujung kaki. Menurut istilah, busana adalah pakaian yang kita kenakan setiap hari dari ujung rambut sampai ujung kai beserta segala perlengkapannya, seperti tas, sepatu, dan segala macam perhiasan/aksesoris yang melekat padanya. ${ }^{13}$

Pakaian (busana) adalah salah satu kebutuhan pokok manusia di samping makanan, (pangan) dan tempat tinggal (papan). Selain berfungsi menutup tubuh, pakaian juga dapat merupakan pernyataan lambang status seseorang dalam masyarakat. Sebab berpakaian ternyata merupakan perwujudan dari sifta dasar manusia yang mempunyai rasa malu sehingga berusaha selalu menutupi tubhnya.

Al-Qur"an menunjukkan kewajiban wanita menutupi tubuhnya dalam firman-Nya QS. An-Nur/24:31
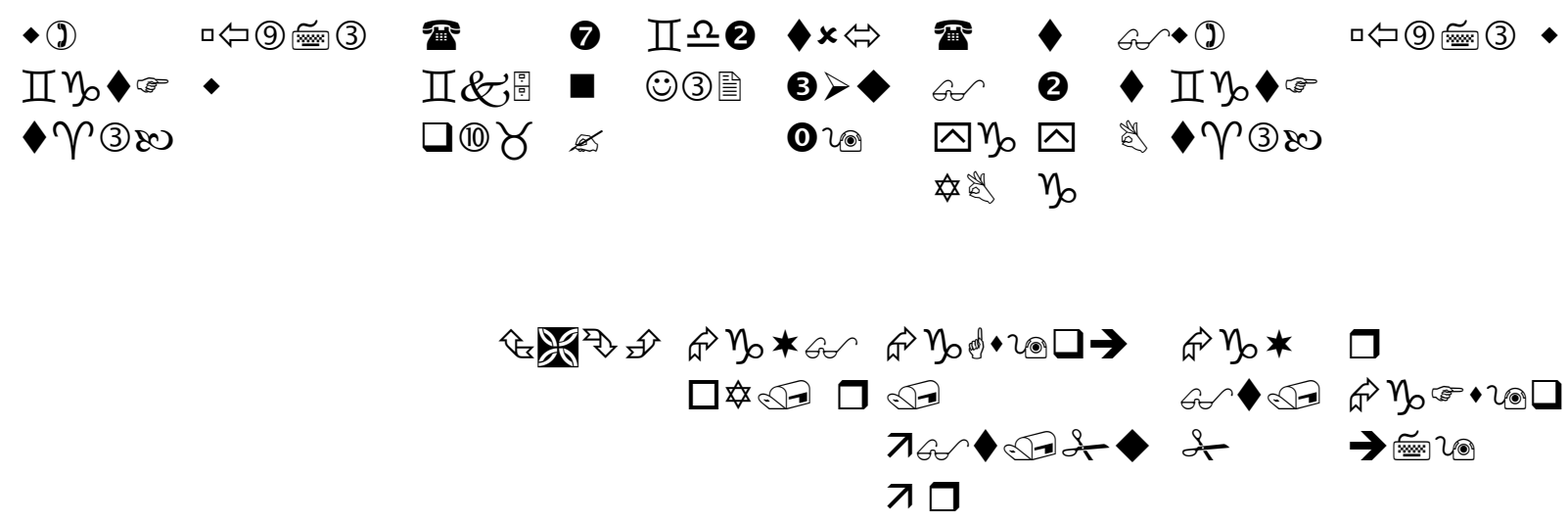
Terjemahnya:

...dan janganlah mereka menampakkan perhiasannya, kecuali yang (biasa) nampak dari padanya. dan hendaklah mereka menutupkan kain kudung kedadanya, dan janganlah Menampakkan perhiasannya... ${ }^{14}$

Yang dimaksud dengan perhiasan disini ialah tempat-tempatnya, bukan apa yang dijasikan perhiasan seperti gelang, kalung anting dan sebagainya. Dengan kata lain yang dimaksud disini ialah keseluruhan tubuh. Dan AllahSWT mengangggap tubuh sebagai perhiasan, adalah sebagai isyarat yang jelas bahwa tubuh wanita merupakan pusat daya tarik bagi lawan jenis. ${ }^{15}$

\section{Fungsi Busana Muslim}

Untuk memahami kembali fungsi-fungsi busana, dapat diperjelas lagi ilustrasi berikut:

1. Busana sebagai penutup aurat

Aurat dalam Al-Qur'an disebut sau'at yang terambil d"eari kata sa'a, yasu'u berarti buruk, tidak menyenangkan. Kata ini sama maknanya bisa dengan aurat yang terambil dari kata ar yang berarti onar, aib, tercela. Kebutuhan yang dimaksud adalah tidak harus dalam arti sesuatu yang pada dirinya buruk, tetapi bisa juga karena adanya faktor lain yang mengakibatkannya buruk.

2. Fungsi busana sebagai perhiasan

Perhiasan merupakan sesuatu yang dipakai untuk memperoleh (memperindah). Tentunya pemakaiannya sendiri harus lebih dahulu mengangaggap bahwa perhiasan tersebut indah kendati orang lain tidak menilai indah atau pada hakikatnya memang tidak indah. AlQurean tidak menjelaskan apalagi merinci apa yang disebut perhiasan, atau sesuatu yang elok.

Hakikat ini merupakan salah satu sebab mengapa Al-Qurean tidak menjelaskan secara rinci apa yang dinilainya indak atau elok. Wahyu kedua yang dinilai oleh ulama sebagai ayatayat yang mengandung informasi pengangakatan Nabi Muhammad SAW. Sebagai Rasul

anatar lain menuntunnya agar menjaga dan terus-menerus meningkatkan kebersiahan pakaiannya. 


\section{E. Kerangka Pikir}

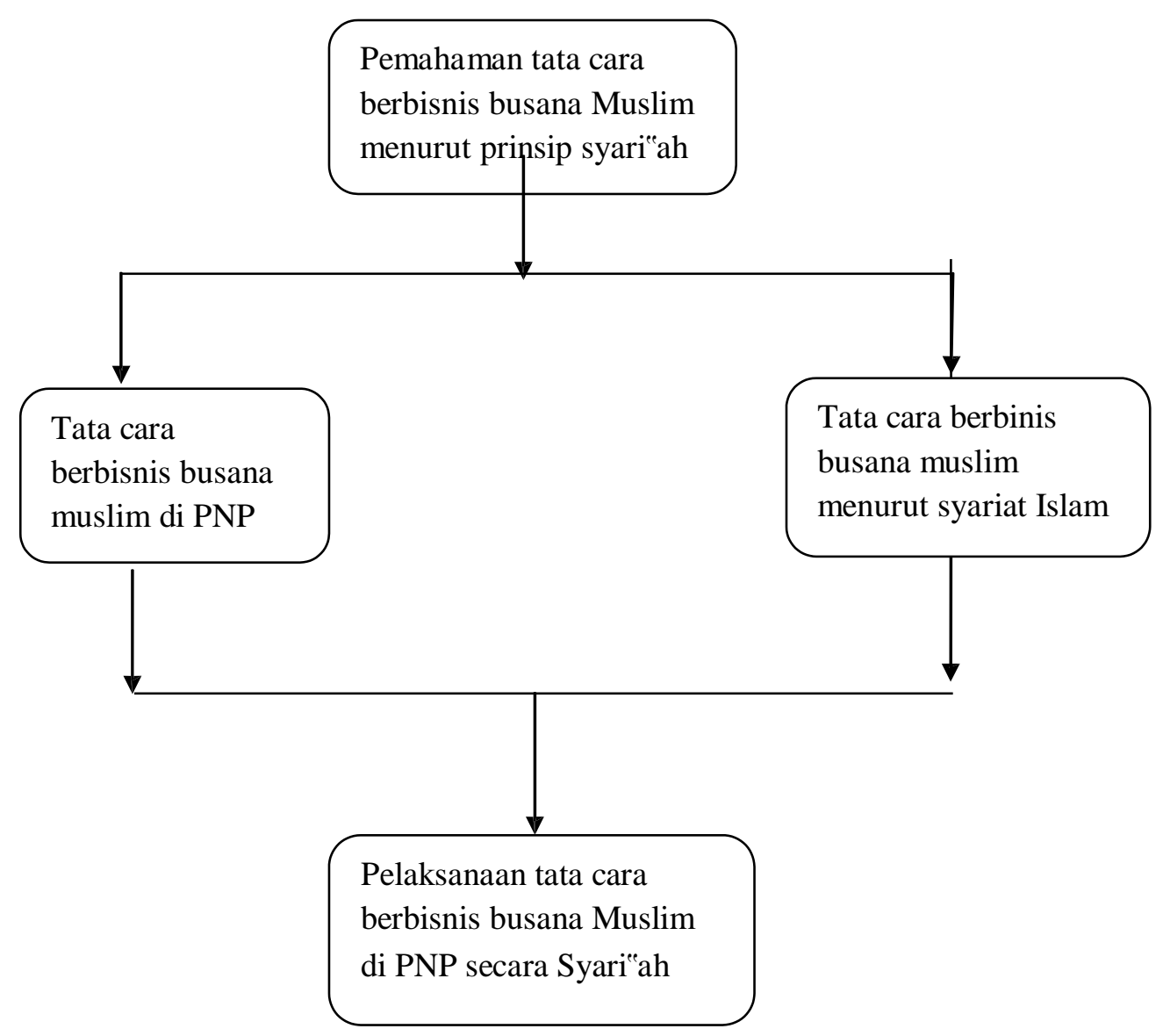

Sebelum melaksanakan tata cara berbisnis maka terlebih dahulu memahami bagaimana tata cara berbisnis busana muslim menurut prinsip syarie ah dimana dalam membuat perjanjian bisnis, selain itu kita harus senantiasa menunjukkan rasa tanggung jawab yang besar dan integrasi yang tinggi dalam berbisnis. Dengan kata lain, kita harus melaksanakan prinsip manajemen bisnis modern yaitu kepuasan pelanggan, pelayanan yang unggul, kemampuan, efesiensi, transparansi, (kejujuran), persaingan yang sehat dan kompetitif. Apabila kita telah melakukan prinsip manajemen tersebut, maka barulah kita bisa melakukan tata cara berbisnis secara syarie $a h$. 


\section{METODE PENELITIAN}

A. Pendekatan dan Jenis Penelitian

Dalam penelitian ini, penulis menggunakan jenis penelitian deskriptif kualitatif yaitu, suatu penelitian yang ditujukan untuk mendeskripsikan menganalisa fenomena peristiwa, aktivitas sosial, sikap, kepercayaan, persepsi, pemikiran orang secara individual maupun kelompok. Penelitian ini diharapkan dapat memberikan gambaran melalui kumpulan data-data yang diperoleh setelah dianalisis, dibuat dan disusun secara sistematik (menyeluruh) dan sistematis yang berupa kata-kata tertulis atau lisan dari orang-orang dan perilaku yang dapat diamati yang memiliki validitas baik, yang bersumber dari bahan kepustakaan (library research), serta dilakukan dengan uraian dan analisis yang mendalam dari data yang diperoleh di lapangan (field research).

B. Lokasi Penelitian

Dalam penelitian ini penulis mengambil lokasi penelitian di Pusat Niaga Palopo Kota Palopo. Adapun alasan saya memilih lokasi tersebut karena tempat tersebut merupakan pusat pembelanjaan dikalangan masyarakat. Adapun alasan memilih lokasi tersebut karena terdapat banyak model dan produk-produk baik dikalangan anak-anak, remaja bahkan orang tua. Dengan seiring berjalannya waktu semakin banyak yang meminati produk-produk busana Muslim utamanya dikalangan para pemuda dan para perempuan.

C. Subjek Penelitian

Dalam penelitian kualitatif posisi narasumber yang dikenal dengan istilah informan sangat penting. Peneliti dan narasumber memiliki posisi yang sama, dan narasumber bukan hanya sekedar memberikan tanggapan pada yang diminta peneliti, tapi ia bisa lebih memilih arah dan selera dalam menyajian informasi yang ia miliki. Adapun yang menjadi informan penelitian ini adalah Pedagang (pemilik toko) Busana Muslim dan Pembeli yang ada di Pusat Niaga Palopo.

\section{Sumber Data}

Sumber data yang digunakan dalam penelitian ini terbagi atas dua bagian yaitu

a. Sumber primer, yaitu data yang diambil langsung dari subjek penelitian yaitu pedagang busana Muslim di Pusat Niaga Palopo kota Palopo.

b. Sumber sekunder, yaitu data yang diambil dari kajian-kajian teori dan karya tulis ilmiah yang relevan dengan masalah yang akan diteliti.

E. Teknik Pengumpulan Data

Pengumpulan data merupakan dari proses pengujian data yang berkaitan dengan sumber dan cara untuk memperoleh data penelitian. Teknik yang digunakan adalah : 
1. Penelitian kepustakaan atau (Library Research) dikumpulkan melalui:

c. Kutipan langsung, yaitu mengutip tanpa merubah redaksi teks yang di kutip sebagaimana teks aslinya. Misalnya buku referensi yaitu buku yang sesuai dengan skripsi ini yang menjadi pedoman penulis dalam penulisan.

d. Kutipan tidak langsung, yaitu mengutp dengan hanya mengambil inti sari atau makna dari teks yang di kutip tanpa mengikuti redaksi aslinya. Contohnya Internet, yaitu mengambil data yang relevan dengan pembahasan melalui media internet.

2. Penelitian lapangan atau (Field Research) dikumpulkan melalui:

a. Observasi

Observasi yang dilakukan adalah observasi berstuktur, yaitu pengamatan yang dilakukan setelah peneliti mengetahui aspek-aspek apa saja dari objek yang diamati yang relevan dengan masalah dan tujuan penelitian. Dalam hal ini peneliti merencanakan hal-hal apa saja yang akan diamati agar masalah yang dipilih dapat dipecahkan. Untuk akurasi data, maka peneliti mempergunakan field notes atau buku catatan lapangan.

\section{b. Interview (wawancara)}

Wawancara adalah proses memperoleh keterangan untuk tujuan penelitian dengan cara tanya jawab sambil bertatap muka antara sipenanya atau pewawancara dengan si penjawab atau responden dengan menggunakan alat yang dinamakan interview guide (panduan wawancara). ${ }^{16}$ peneliti melakukan wawancara dengan pihak-pihak terkait dengan maksud untuk melengkapi data yang diperoleh melalui observasi.

F. Teknik Pengolahan dan Analisis Data

Analisis data adalah proses pengorganisasian dan mengurutkan data kedalam pola, kategori, dan uraian dasar. Sedangkan data yang dimaksud adalah yang berasal dari cacatan lapangan, hasil wawancara, dan komentar peneliti.

Adapun data yang telah diolah selanjutnya dianalisis dengan metode kualitatif deskriptif kemudian mengambil kesimpulan dengan beberapa teknik sebagai berikut:

a. Teknik induktif, yakni menganalisa data dari hal-hal yang bersifat khusus dan menarik kesimpulan yang sifatnya umum.

b. Teknik deduktif, yakni mengkaji dan menganalisa data yang bersifat umum dan menarik kesimpulan yang bersifat khusus. ${ }^{17}$

\footnotetext{
${ }^{16}$ Moh. Nazir, Metode Penelitian, (Cet Vi; Bogor: Ghalia Indonesia, 2005 ), h. 194.

${ }^{17}$ Sutrisno Hadi, Metodologi Research, Jilid I, (Cet. XXII; Yogyakarta: Andi Offset, 1990), h. 49.
} 


\section{Pembahasan dan Hasil Penelitian}

A. Pembahasan hasil penelitian

Pemahaman tata cara berbisnis menurut prinsip syariah di pusat niaga palopo

Pedagang sebagai salah satu komponen dalam transaksi berdagang merupakan posisi yang sangat menentukan keberhasilan dalam transaksi perdagangan, karena fungsi utama pedagang adalah mencari barang yang halal lagi baik, karena mereka yang mengelola dan memiliki barang yang akan dijual kepada pembeli.

Dalam Islam, adapun bentuk berbohong untuk mendapat keuntungan pribadi dan mengakibatkan orang lain menjadi tertipu jelas dilarang karena hal ini bertentangan dengan prinsip keadilan, dimana penjual dan pembeli seharusnya saling mendapat keuntungan secara adil dari hasil transaksi yang dilakukan keduanya (penjual dan pembeli).

Islam adalah agama yang membimbing manusia untuk berprilaku dan bertindak sesuai dengan yang dianjurkan oleh Islam itu sendiri. Dalam ajaran Islam, Nabi Muhammad SAW telah memberikan contoh yang benar dalam berdagang yang sesuai denagn syariat Islam yaitu bersikap jujur kepada pembeli dengan menjelaskan keadaaan barang yang dijual meskipun hal terseut dapat merugikannya, dengan menjelaskan keadaan barang misalkan ada yang rusak dan memisahkannya dengan barang yang masih bagus. Tegaknya syarie ah Islam ditentukan oleh sejauh mana umat Islam melaksanakan syarie ah Islam dalam aspek kehidupannya. Secara prinsip aktifitas bisnis tidak boleh lepas dari nilai-nilai spiritual. Sebagaina aktifitas bisnis tidak dapat terpisahkan dari nilai-nilai akhlaqi. Sehingga antara agama, etika, dan bisnis saling berkaitan antara satu sama lain. Dalam hal ini bisnis yang menguntungkan adalah bisnis yang sesuai dengan ajaran al-Quree an yaitu yang didalamnya terdapat kolaborasi antara bisnis, etika dan agama.

Etika dalam bisnis sangatlah penting. Hal ini tidak hanya berlaku dalam bisnis Islam tetapi juga pada umumnya. Karena dengan adanya etika, aktifitas bisnis berjalan rapi, dan seimbang. Dengan adanya etika, maka aturan-aturan dalam bisnis dapat terbentuk. Dan lebih utama apabila aturan-aturan dalam bisnis menerapkan etika yang Islami sesuai dengan ajaran syar"i.

Hal tersebut merupakan hal yang paling jarang kita temui di Pasar Sentral Palopo ini yaitu pedagang yang berkata jujur kepada pembeli dengan kualitas barang dijual karena takut apabila pembeli tersebut tidak jadi membelinya. Padahal yang dialami Nabi Muhammad malah sebaliknya, para pembeli malah berbondong-bondong untuk berbelanja ditempatnya karena mereka percaya dengan kualitas serta harga yang ditawarkan Muhammad pada saat itu. 
Sekarang yang ada malah para penjual selalu menutupi kekurangan dari barang dagangannya hanya menyebutkan kelebihan produk yang dijualnya. Dalam Islam hal tersebut tentu saja dilarang oleh Allah SWT karena ada pihak yang akan merasa dirugikan karena merasa tertipu dengan barang yang dibelinya.

Kenyataannya, penegakan syarieeah Islam masih memerlukan upaya-upaya yang lebih instensif sehingga syarie ah Islam benar-benar dapat terwujud dalam berbagai sendi kehidupan, termasuk dalam hal berbisnis. Lemahnya pemahaman umat Islam terhadap ajaran dan tuntunan agama Islam dalam berbisnis akan berdampak pada praktek jual beli yang sangat jauh dari tuntunan dan syarieeah Islam, untuk mengetahui lebih jauh lagi dalam penerapan prinsip-prinsip ekonomi syarie ah dapat dilihat sebagai berikut:

a. Deskripsi tentang tingkat pemahaman bisnis para pedagang busana muslim

Dari hasil observasi dan wawancara yang penulis lakukan dengan beberapa pedagang diantaranya Ibu Hajeriah mengenai pemahaman pedagang tentang berbisnis busana muslim yang sesuai dengan syariee ah di pusat niaga Palopo mengatakan bahwa:

Pernah mendengar tetapi tidak memahaminya. Menurutku apa yang sekiranya tidak merugikan orang lain dalam hal ini pembeli, maka itu sudah baik dan tidak melanggar nilai moral dan etika dalam agama. Saya memahaminya berdasarkan pengetahuan yang saya dengar dari ceramah-ceramah agama. ${ }^{18}$

Sedangkan menurut Hafsah mengatakan bahwa:

Dalam berbisnis busana muslim ini yang terpenting tidak merugikan orang lain serta tidak melakukan kecurangan. Walaupun saya tidak begitu memahami tentang bisnis yang Islami. Tetapi saya berusaha menerapkan sikap-sikap jujur dalam berdagang. ${ }^{19}$

Dari semua pedagang mengatakan hal yang sama bahwa mereka pernah mendengar tentang bisnis yang sesuai dengan syariecah tetapi belum terlalu memahaminya. Dari pengamatan yang penulis lakukan masih banyak menemui pedagang yang tidak mengenal waktu dalam berbisnis. Seperti pada waktu ibadah hari jumat banyak pedagang yang masih sibuk dengan aktifitasnya. Padahal al-Qurean mewajibkan umat Islam meninggalkan aktifitas apapun dan segera mengingat Allah jika mereka mendengar adzan pada hari jumeat. Jadi segala macam interaksi dalam bentuk apapun yang bisa mempengaruhi perhattian sholat harap

\footnotetext{
${ }^{18}$ Hajeriah, Pedagang, Wawancara, Palopo, Rabu, Tanggal 15 Juni 2016 Pukul 14.01

${ }^{19}$ Hafsah, Pedagang, Wawancara, Palopo, Rabu, Tanggal 15 Juni 2016 Pukul 14.35
} 
untuk ditinggalkan. Hal ini menunjukkan bahwa hubungan iman dengan bisnis sangatlah erat. Berbisnis yang tidak mengenal waktu memang akan mendatangkan keuntungan besar dan dapat mempercepat perputaran roda perekonomian. Namun hal ini tidaklah sesuai dengan ajaran Islam.

Oleh karena itu, pemahaman pedagang tentang bisnis busana muslim yang Islami sangat penting, karena jika mereka memahami tentang bisnis yang Islami maka akan berdampak pada cara berbisnis mereka. Dalam bertransaksi misalnya mereka akan lebih berhati-hati dan senantiasa tidak melakukan kecurangan yang akibatnya dapat merugikan orang lain.

Hasil wawancara yang dilakukan oleh penulis oleh ibu Mariana (pembeli) mengatakan bahwa:

Para penjual selalu mengatakan barangnya bagus, sehingga para konsumen tertarik membelinya meskipun dengan harga yang cukup tinggi. Kadang kami selalu merasa ditipu, tetapi barang yang sudah diberi tidak boleh dikembalikan. ${ }^{20}$

Dalam bisnis Islam terdapat aturan-aturan dan nilai-nilai yang dapat menghantarkan manusia dalam kehidupannya menuju tujuan kebahagiaan hidup baik di dunia maupun diakhirat.

b. Deskripsi barang yang diperjual belikan.

Dalam pandangan syarieeah Islam, berdagang yang dilakukan harus memenuhi beberapa kriteria di antaranya adalah bahwa interaksi jual beli harus memegang teguh prinsip yg baik dn tidak merugikan, artinya baik penjual maupun pembeli, barang yang diperjual belikan serta transaksi yang dilakukan harus memenuhi kriteria yang baik yang diharapkan akan menjadi transaksi yang menguntungkan kedua belah pihak. Tidak ada yang dirugikan dan merugikan.

Hasil wawancara yang dilakukan oleh bapak Andi, mengenai barang yang diperjual belikan mengatakan:

Saya (bapak Andi) tidak pernah menjual barang yang kualitasnya jelek dalam artian tidak layak untuk diperjual belikan. Barang yang saya jual adalah barang-barang yang kuallitasnya benar-benar bagus, karena saya tidak mau pelanggan saya kecewa dengan barang saya dan saya tidak ingin merugikan masyarakat atau pelanggan saya. ${ }^{21}$

\footnotetext{
${ }^{20}$ Mariana, Pembeli, Wawancara, Palopo, minggu, 14 Agustus 2016 pukul 14.15

${ }^{21}$ Andi, Pedagang, Wawancara, Palopo, Rabu, Tanggal 15 Juni 2016 Pukul 15.00
} 
Lanjut wawancara Pat (penjual) mengatakan:

Setiap tahun kami selalu menyediakan barang-barang terbaru agar konsumen selalu tertarik dan tidak merasa bosan dalam memilih barang tersebut. ${ }^{22}$

Memang aspek kehidupan dalam Islam sangatlah ditentukan. Pedagang diwajibkan untuk menjual komoditas yang suci dan bersih. Tujuan Islam dari semua ini adalah agar tercipta kehidupan manusia yang aman dan sejahtera.

c. Deskripsi tentang kualitas dan jenis barang yang diperjual belikan.

Setiap pelaku bisnis dalam perdagangan atau dalam menjalankan usahanya hendaknya tidak semata-mata bertujuan mencari keuntungan sebesar-besarnya akan tetapi untuk mencari keridoan Allah dan mencapai keberkahan atas rezki yang diberikan oleh Allah SWT. Dimana dalam mekanisme kerja pasar dibangun atas dasar kebebasan, yaitu kebebasan individu untuk melakukan transaksi barang dan jasa yang sesuai dengan penawar dan peminta sukai dengna catatan tidak menimbulkan kerugian baik bagi diri sendiri maupun orang lain sehingga tidak terjadi konflik kepentingan, selain ini diperlukan kerja sama antara satu masyarakat dengan masyarakat yang lain untuk mewujudkan kehidupan ynag sejahtera secara bersama. Walaupun dalam Islam telah memberi ketentuan pasar dalam penetapan harga jangan berbuat kecurangan dalam menawarkan harga karena dengan menawarkan harga yang begitu tinggi maka akan membuat resah pembeli yang tidak pintar menawar. Hasil wawaqncara tentang harga yang dilakukan oleh penulis oleh ibu rida, penjual di pasar sentral palopo menngatakan:

Kami selalu memberikan harga yang relatif murah kepada pembeli atau kepada konsumen, agar konsumen tetap menjadi pelanggan kami. ${ }^{23}$

Dengan prinsip kebebasan dan kejujuran penjual akan memperoleh keuntungan dari hasil dagangannya. Karena jika aspek kejujuran ditanamkan dan dipakai dalam berdagang maka pembeli akan lebih percaya dan ini sangat menguntungkan pedagang sebab mereka para pembeli akan menjadi lebih nyaman untuk berbelanja ditempatnya sehingga keuntungan akan lebih meningkat apalagi pada hari-hari besar seperti menjelang hari raya Idul Fitri, Idul Adha, Natal dan Tahun Baru. Karena hari-hari seperti ini minat belanja masyarakat hampir semuanya meningkat.

\footnotetext{
${ }^{22}$ Pat. Pedagang, Wawancara, Palopo, Minggu, 14 Agustus 2016 pukul 15.00

${ }^{23}$ Rida, Pedagang, Wawancara, Palopo, Minggu, tanggal 14 Agustus 2016, pukul 15.05
} 
Hasil observasi yang peneliti temui dilapangan masih banyak pedagang yang menutup nutupi tentang kondisi keadaan barang yang dijualnya. Misalnya ada cacat atau rusak. Hasil wawancara yang penulis lakukan kepada ibu Mulia selaku pembeli di pasar sentral palopo mengatakan:

Banyak penjual yang demi kepentingan pribadi untuk mendapatkan keuntungan yang lebih besar rela berbohong dengan tidak secara terbuka dalam menginformasikan kondisi barang kepada pembeli. ${ }^{24}$

Lanjut wawancara yang dilakukan penulis oleh Ibu Fatimah (pembeli) di PNP mengatakan bahwa :

Banyak penjual yang tidak jujur dalam melakukan proses penjualan barang dagangan mereka. Mereka mengatakan barang itu sudah tidak bidak bisa di tawar-tawar lagi karena itu sudah harga pas, tetapi sebenarmya untung yang mereka dapat sudah ada, malahan mereka mengatakan saya tidak mendapat keuntungan lagi dari harga yang ibu/bapak tawarkan. ${ }^{25}$

Sistem tata cara berdagang busana muslim memberikan harga sangatlah tinggi yang tidak sesuai dengan harga barang yang di jual. ${ }^{26}$

Riba menimbulkan mental boros dan malas yang hanya mendapatkan harta tanpa kerja keras. Padahal Islam sangat menganjurkan untuk saling tolong menolong dan melarang mengutamakan diri sendiri. Karena tujuan dari usaha atau bisnis sebenarnya dalam Islam tidak hanya untuk mencari keuntungan yang setinggi-tingginya tetapi juga harus bisa memberikan manfaat dan keuntungan kepada lingkungan seperti terciptanya suasana persaudaraan, kepedulian sosial, dan sebagainya. Tiap harta yang dimiliki akan dimintai pertanggung jawaban dihadapan Allah.

Islam sangat melarang keras riba karena kehormatan harta manusia sama dengan kehormatan darahnya. Oleh karena itu mengambil harta orang lain tanpa ganti adalah haram. Riba akan menyebabkan terputusnya sikap yang baik antar sesama.

Hal tersebut disebutkan dalam QS. Al-Baqarah/1:276

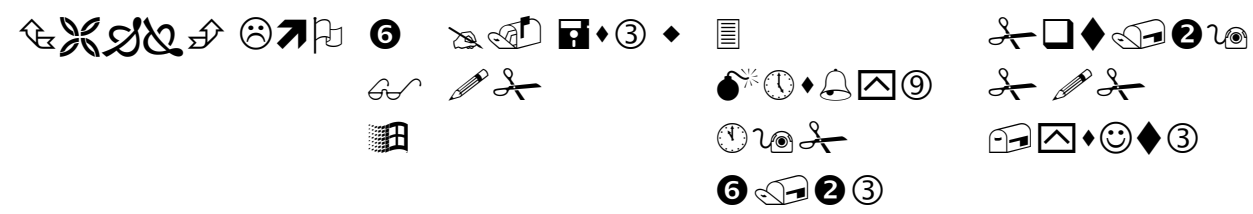

Terjemahnya:

\footnotetext{
${ }^{24}$ Mulia, Pembeli, Wawancara, Palopo, jumat, 17 Juni 2016 Pukul 14.43

${ }^{25}$ Fatimah, Pembeli di Pusat Niaga Palopo, “wawancara” sabtu, 18 Juni 2016 Pukul 12.35

${ }^{26}$ Mitha, Pembeli, Wawancara, PNP, Minggu, 14 Agustus 2016, pukul 16.15
} 
Allah memusnahkan Riba dan menyuburkan sedekah. Dan Allah tidak menyukai Setiap orang yang tetap dalam kekafiran, dan selalu berbuat dosa. ${ }^{27}$

Sesungguhnya Allah memberikan syariee at bagi para hambanya sesuatu hal yang dapat mendidik mereka agar mempunyai sifat tolong-menolong bukan membahayakan satu sama lain, terlebih lagi ketikaada orang yang sangat membutuhkan pertolongan. Karean itu Allah mengaharamkan riba bagi para hambanya karen adapat membelenggu kesulitan saudaranya, dan menghalalkan jual beli yang tujuannya tidak mengambil keuntungan dengan memaka harta orang lain. Dan apapun yang dilakukan dalam usaha mencari rezeki harus diridhoi oleh Allah SWT sehingga mendapat berkah dan melakukannya dengan jujur, tidak curang, dan tidak mengandung unsur penipuan dan riba.

\section{KESIMPULAN}

Berdasarkan uraian dan pembahasan pada bab-bab sebelumnya, maka penulis menarik kesimpulan bahwa, tata cara berdagang busana muslim menurut syariat Islam di PNP adalah deskripsi tingkat pemahaman penjual tentang tata cara berbisnis sudah sesuai dengan prinsip syarieeat Islam. Dan deskripsi yang diperjualkan barang-barang yang bagus dan tidak mengecewakan konsumen. Kualitas dan jenis barang, sebagian pembeli mengatakan bahwa penjual tidak jujur dan kualitas barangnya. Dan Pembeli merasa bahwa penjual menerapkan unsur riba.

Jadi dapat disimpulkan bahwa pedagang busana muslim di Pusat Niaga Palopo sebagian tidak menerapkan tata cara bisnis Islam, tetapi ada sebagian pedagang busana muslim menerapkan tata cara bisnis Islam.

\section{SARAN}

Adapun saran-saran yang sesuai dengan judul skripsi ini adalah:

1. Kepada seluruh masyarakat pada umumnya agar senantiasa menerapkan transaksitransaksi saat berbisnis untuk memenuhi kebutuhan hidup kiranya dilakukan secara baik dan halal sesuai dengan petunjuk al-Qurean dan jangan melakukan dengan cara-cara yang diharamkannya.

2. Diperlukan pemmbinaan kepada pedagang khususnya para pedagang Pusat Niaga Palopo terhadap penanaman nilai-nilai syarie ${ }^{\text {ah }}$ yang terkait dengan perdagangan. Karena kalau

\footnotetext{
${ }^{27}$ Departemen Agama RI., h.47
} 
perkembangan perekonomian tidak diikuti dengan pembinaan mental, spiritual, dan teknik perdagangan, dikhawatirkan akan hilangnya nilai-nilai syarie ah dalam prilaku bisnis para pedagang. Pembinaan yang dilakukan dapat berupa pelatihan-pelatihan tentang cara menjalankan usaha yang baik dan diharapkan para muballiq tidak hanya memberikan ceramah atau kajian yang relevan dengan perilaku bisnis yang Islami khususnya dan ekonomi syariee ah umumnya.

\section{DAFTAR PUSTAKA}

Andi, Pedagang, Wawancara, Palopo, Rabu, Tanggal 15 Juni 2016 Pukul 15.00

As-Syaeerawi Syaikh Mutawalli, Fiqih Perempuan (Muslimah), Jakarta: Amzah, 2003

Badroen Faisal. Dkk, Etika Bisnis Dalam Islam, Ed. I; Cet. II; Jakarta : Kencana, 2007

Bukhari Alma, Pengantar Bisnis, Bandung : Alfabeta, 1998

Departemen Agama RI, Al-Qur'an dan Terjemahnya, Cet. 3; Semarang: PT. Karya Toha Putra, 2002

Departmenen Agama RI, Al-Qur"an dan Terjemahannya, Bandung: CV. Penerbit Jumanatul „Ali-art (J-Art), 2005.

Fatimah, Pembeli di Pusat Niaga Palopo, “wawancara” sabtu, 18 Juni 2016 Pukul 12.35

Hadi Sutrisno, Metodologi Research, Jilid I, Cet. XXII; Yogyakarta: Andi Offset, 1990

Hajeriah, Pedagang, Wawancara, Palopo, Rabu, Tanggal 15 Juni 2016 Pukul 14.01

Hafsah, Pedagang, Wawancara, Palopo, Rabu, Tanggal 15 Juni 2016 Pukul 14.35

http://www.docstoc.com/docs/124537345/24005257-pengertian -pakaian/diakses tanggal 13 januari 2016.

http://mamaulis.blogspot.co.id//butik busana muslim mamtaza.html.diakses tanggal 20 desember 2015.

http://hidayatulrahman.wordpress.com/tag/add-new-tag/diakses tanggal 14 januari 2016. 
http://poniran.abatasa.co.id/post/detail/4990/busana-muslimah.html/diakses tanggal 14 januari $\underline{2016 .}$.

Jusmialiani, Bisnis Berbasis Syari'ah, Jakarta: Bumi Aksara, 2008

Lukman Fauroni dkk, Visi Al-Qur'an Tentang Etika dan Bisnis, Cet. I:Jakarta: Salemba

Mariana, Pembeli, Wawancara, Palopo, minggu, 14 Agustus 2016 pukul 14.15

Mitha, Pembeli, Wawancara, PNP, Minggu, 14 Agustus 2016, pukul 16.15

Mulia, Pembeli, Wawancara, Palopo, jumat, 17 Juni 2016 Pukul 14.43

Muhammad, Prinsip-prinsip Ekonomi Islam, Yogyakarta: Graha Ilmu, 2007

Nazri Moh,, Metode Penelitian, Cet Vi; Bogor: Ghalia Indonesia, 2005.

Pat. Pedagang, Wawancara, Palopo, Minggu, 14 Agustus 2016 pukul 15.00

Rida, Pedagang, Wawancara, Palopo, Minggu, tanggal 14 Agustus 2016, pukul 15.05

Sudarsono, Etika Islam Tentang Kenakalan Remaja, Jakarta : Bina Aksara, 1989 